\title{
Pemisahan dan identifikasi komponen-komponen utama minyak atsiri dari daun cengkeh segar dan kering (Syzygium aromaticum)
}

\author{
Martha Tuganitya*, Sanusi Gugule, I Dewa Ketut Anom
}

Kimia, Universitas Negeri Manado, Tondano, 95618

\begin{tabular}{l} 
I N F O A R T I K E L \\
\hline Diterima 15 Agustus 2019 \\
Disetujui : 30 Agustus 2019 \\
\\
\hline Key word: \\
Clove leaves, \\
volatile oil, \\
eugenol, \\
caryophyllene. \\
\hline Kata kunci: \\
Daun cengkeh, \\
minyak atsiri, \\
eugenol, \\
kariofilen.
\end{tabular}

*e-mail: marthatuganyita@gmail.com *Telp: 085241449707

\begin{abstract}
A B STR A C T
This study aims to separate and identify the main components of essential oils from fresh clove and dried clove leaves through a steam distillation process. The resulting are dried with $\mathrm{Na}_{2} \mathrm{SO}_{4}$ and obtained $0.6203 \mathrm{~mL}$ of fresh clove oil and $2.2014 \mathrm{~mL}$ of dried clove oil. Clove oil was identified using IR and GC-MS. IR analysis shows that fresh oil has a wavelength of 3510.45-3448.72 $\mathrm{cm}^{-1}$ and the presence of an OH group, 2924.09-2846.93 cm-1 there is an aliphatic $C-H$ group, $3070.68 \mathrm{~cm}^{-1}$ the presence of a benzene C-H group and $1604.77 \mathrm{~cm}^{-1}$ indicate the presence of benzene groups. Dry clove oil has a wavelength of 3518.16-3456.44 $\mathrm{cm}^{-1}$, the presence of $\mathrm{OH}$ groups, $2931,8-2846.3 \mathrm{~cm}^{-1}$, the presence of aliphatic $C-H$ groups, 3070,68 $\mathrm{cm}^{-1}$ presence of $C$ $H$ benzene groups and $1604,77 \mathrm{~cm}^{-1}$ indicate the presence of benzene groups. The results of the GC-MS chromatogram analysis of fresh clove oil and dried clove oil showed 7 peaks which showed 7 compounds. Of the 7 peaks produced, the highest peak has similarities with the chromatogram of eugenol and caryophyllene.
\end{abstract}

\section{A B STRAK}

Penelitian ini dilakukan dengan tujuan pemisahan dan identifikasi komponen-komponen utama minyak atsiri dari daun cengkeh segar dan kering melalui proses destilasi uap. Hasil destilasi uap dikeringkan dengan $\mathrm{Na}_{2} \mathrm{SO}_{4}$ dan diperoleh minyak cengkeh segar dan kering sebanyak 0,6203 mL dan 2,2014 mL. Minyak cengkeh diidentifikasi menggunakan alat IR dan GCMS. Hasil analisis IR menunjukkan bahwa minyak cengkeh segar memiliki panjang gelombang $3510,45-3448,72 \mathrm{~cm}^{-1}$ adanya gugus $\mathrm{OH}, 2924,09-2846,93$ $\mathrm{cm}^{-1}$ adanya gugus $\mathrm{C}-\mathrm{H}$ alifatik, $3070,68 \mathrm{~cm}^{-1}$ adanya gugus $\mathrm{C}-\mathrm{H}$ benzena, 1604,77 andanya gugus benzena. Sedangkan minyak cengkeh kering memiliki panjang gelombang $3518,16-3456,44 \mathrm{~cm}^{-1}$ adanya gugus $\mathrm{OH}, 2931,8-2846,3 \mathrm{~cm}$ 1 adanya gugus $\mathrm{C}-\mathrm{H}$ alifatik, $3070,68 \mathrm{~cm}^{-1}$ adanya gugus $\mathrm{C}-\mathrm{H}$ benzena dan $1604,77 \mathrm{~cm}^{-1}$ adanya gugus benzen. Hasil analisis kromatogram GC-MS dari minyak cengkeh segar dan kering masing-masing menunjukan adanya 7 puncak yang artinya ada 7 senyawa. Dari 7 puncak yang dihasilkan puncak yang paling tinggi memiliki kesamaan dengan kromatogram eugenol dan kariofilen.

\section{Pendahuluan}

Untuk memisahkan komponen-komponen utama minyak daun cengkeh segar. Untuk mengidentifikasi komponen-komponen utama minyak daun cengkeh kering dengan menggunakan alat Inframerah (IR) dan Gas Chromatography Mass Spectrometry (GC-MS).

Salah satu produk unggulan Indonesia yang menghasilkan komoditas besar adalah tanaman cengkeh (Syzygium aromaticum). Perkebunan cengkeh diusahakan oleh rakyat lebih kurang 95\% dalam bentuk perkebunan rakyat yang tersebar di seluruh provinsi di Indonesia dan sisanya sebesar 5\% diusahakan oleh perkebunan swasta dan perkebunan negara [1]. Tanaman cengkeh berpotensi sebagai penghasil minyak atsiri. Minyak atsiri cengkeh sangat diperlukan dalam berbagai industri seperti bahan baku dalam perisa maupun pewangi makanan (flavour and fragrance ingredients), industri kosmetik, industri farmasi, industri bahan pengawet dan bahan insektisida. 
Tanaman cengkeh yang berumur lebih dari 20 tahun, setiap minggunya dapat terkumpul daun kering sebanyak rata-rata $0,96 \mathrm{~s} \mathrm{~kg} /$ pohon, sedangkan tanaman yang berumur kurang dari 20 tahun dapat terkumpul sebanyak 0,46 $\mathrm{kg} /$ pohon [2].

Daun cengkeh merupakan hasil dari pohon cengkeh yang belum banyak dimanfaatkan oleh petani dibandingkan dengan bunga atau tangkai cengkeh yang banyak digunakan untuk industri rokok dan makanan [3]. Minyak daun cengkeh mengandung komponen utama yaitu eugenol (80\%- 90\%) dan kariofilena [4]. Saat ini usaha pemanfaatan eugenol mulai banyak dilakukan. Dua senyawa turunan eugenol yang banyak dimanfaatkan adalah metileugenol dan metilisoeugenol. Metileugenol dapat dibuat dari reaksi metilasi senyawa eugenol dan dapat digunakan sebagai sex attractant dalam jumlah sedikit. Metileugenol memiliki gugus allil yang dapat diubah menjadi gugus alkohol yang selanjutnya dapat dioksidasi menjadi senyawa aldehid (3-(3,4-dimetoksifenil)-propanal) yang merupakan senyawa antara dalam sintesis turunan antibiotik C-9154.

Pohon cengkeh memiliki bau yang khas yang berasal dari minyak atsiri yang terdapat bunga (10-20\%), gagang (5-10\%) dan daun (1$4 \%$ ) [1]. Daun cengkeh mengandung minyak 1$4 \%$ baik daun kering maupun daun segar, sehingga dapat ekstraksi menjadi minyak atsiri yang bernilai ekonomis tinggi. Komponen terbesar yang terdapat dalam minyak atsiri cengkeh adalah eugenol sebesar $70-80 \%$. Pada umumnya daun cengkeh cenderung dibuang karena dianggap sebagai sampah padahal dapat menghasilkan minyak serta memiliki nilai lebih ekonomis.

\section{Bahan dan Metode}

Peralatan yang digunakan adalah rangkaian alat destilasi uap, corong pisah, corong biasa, gelas ukur, gelas kimia, tabung reaksi, stopwatch, timbangan digital, alumunium foil, colokan, labu ukur; pipet; seperangkat alat IR dan GC-MS. Bahan yang digunakan adalah daun cengkeh (Syzygium aromaticum) yaitu daun kering dan daun segar, $\mathrm{Na}_{2} \mathrm{SO}_{4}$, aquades, es batu.

\section{Tahap Preparasi Sampel}

Perlakuan untuk daun cengkeh kering dipetik dari pohon, kemudian dikumpulkan, dikeringkan dibawah sinar matahari secara langsung selama beberapa hari sampai kering. Setelah itu dihaluskan, ditimbang, dimasukan kedalam labu, ditambahkan aquades. Kemudian proses destilasi uap dimulai. Untuk daun cengkeh segar, dipetik dari pohon, kemudian dikumpulkan, diiris. Setelah itu dihaluskan, ditimbang, dimasukan kedalam labu kejal, diisi aquades, dilakukan destilasi uap.

Daun cengkeh kering, sebanyak 30 gram, aquades $800 \mathrm{ml}$ dimasukan kedalam labu desilasi, digabungkan pada alat destilasi uap hingga sampel mendidih, hitung waktu sampai menghasilkan minyak. Proses yang sama menggunakan daun cengkeh segar hingga menghasilkan minyak.

\section{Hasil dan Pembahasan}

Destilasi Uap

Sebanyak 30 gram, daun cengkeh kering dan segar digunakan untuk proses ektraksi. Proses ekstraksi menggunakan metode destilasi uap. Destilasi uap merupakan pemisahan yang menggunakan penambahan uap pada bahan yang akan didestilasi. Metode destilasi uap pada daun cengkeh kering dan segar masing-masing dilakukan 5 kali proses pengulangan.

Sampel digerus kemudian ditimbang sebanyak 300 gram dan dimasukkan kedalam labu destilasi, selanjutnya ditambahkan aquades sebanyak $800 \mathrm{~mL}$. Dipanaskan pada rangkaian alat destilasi uap selama 3 jam, uap yang dihasilkan dikondensasi dan distilat yang berupa campuran minyak dan air dipisahkan dengan menggunakan corong pemisah. Perolehan minyak dikeringkan dengan sodium sulfat anhidrat $\left(\mathrm{Na}_{2} \mathrm{SO}_{4}\right)$ untuk memisahkan minyak dari sisa air yang masih tertinggal dan menghasilkan minyak daun cengkeh segar dan kering. 
Identifikasi Inframerah Minyak Atsiri (MA) Daun Cengkeh Kering Dan Segar

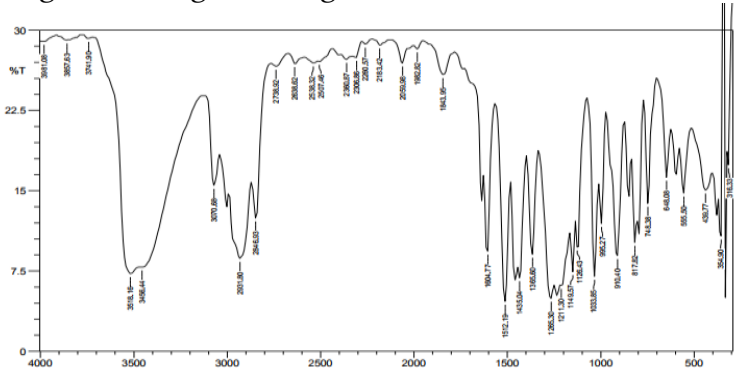

Gambar 1. Identifikasi gugus fungsi minyak atsiri (MA) daun cengkeh kering menggunakan IR.

Tabel 1. Data inframerah minyak atsiri daun cengkeh kering

\begin{tabular}{|c|c|c|c|}
\hline$\lambda\left(\mathrm{cm}^{-1}\right)$ & Intensitas & $\begin{array}{c}\text { Bentuk } \\
\text { pita }\end{array}$ & $\begin{array}{c}\text { Dugaan } \\
\text { gugus }\end{array}$ \\
\hline $\begin{array}{l}3518,16- \\
3456,44\end{array}$ & Kuat & Lebar & $\mathrm{OH}$ \\
\hline $\begin{array}{c}2931,8- \\
2846,3\end{array}$ & Kuat & Tajam & $\begin{array}{c}\mathrm{C}-\mathrm{H} \\
\text { alifatik }\end{array}$ \\
\hline 3070,68 & Lemah & Tajam & $\begin{array}{c}\text { C-H } \\
\text { benzena }\end{array}$ \\
\hline 1604,77 & Kuat & Tajam & Benzena \\
\hline
\end{tabular}

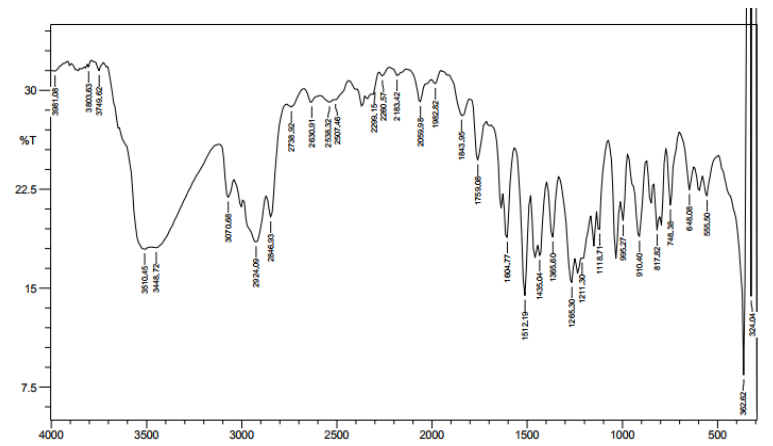

Gambar 2. Identifikasi gugus fungsi minyak atsiri (MA) daun cengkeh segar menggunakan IR.

Tabel 2. Data inframerah minyak atsiri daun cengkeh segar.

\begin{tabular}{|c|c|c|c|}
\hline$\lambda\left(\mathrm{cm}^{-1}\right)$ & Intensitas & $\begin{array}{c}\text { Bentuk } \\
\text { pita }\end{array}$ & $\begin{array}{c}\text { Dugaan } \\
\text { gugus }\end{array}$ \\
\hline $\begin{array}{l}3510,45- \\
3448,72\end{array}$ & Sedang & Lebar & $\mathrm{OH}$ \\
\hline $\begin{array}{c}2924,09- \\
2846,93\end{array}$ & Sedang & Tajam & $\begin{array}{c}\mathrm{C}-\mathrm{H} \\
\text { alifatik }\end{array}$ \\
\hline 3070,68 & Sedang & Tajam & $\begin{array}{c}\mathrm{C}-\mathrm{H} \\
\text { benzene }\end{array}$ \\
\hline 1604,77 & Sedang & Tajam & Benzena \\
\hline
\end{tabular}

Analisis Gas Chromatography-Mass Spektrometry (GC-MS)

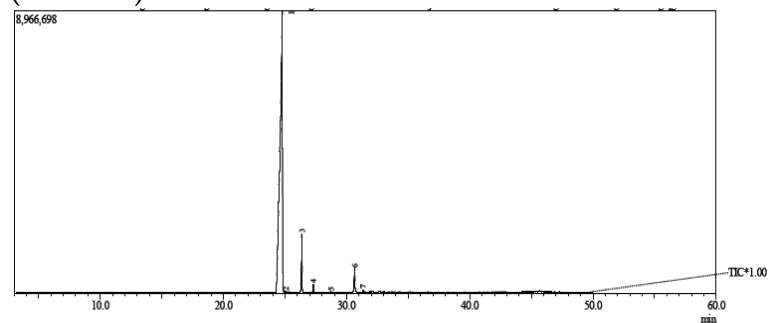

Gambar 3. Hasil GC-MS minyak minyak atsiri daun cengkeh kering.

Hasil analisis kromatogram GC dipaparkan pada Gambar 3 menunjukan adanya 7 puncak yang artinya ada 7 senyawa. Senyawa yang paling dominan teridentifikasi adalah senyawa dengan nomor puncak $1,3,5$, dan 6. Analisis dengan spektra massa menunjukan bahwa spektra massa puncak 1 adalah senyawa eugenol dan spektra massa puncak 3 yaitu kariofilen.

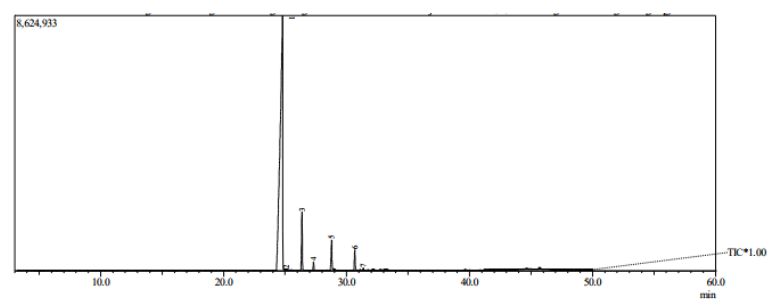

Gambar 4. Identifikasi GC-MS minyak atsiri (MA) daun cengkeh segar.

Hasil analisis kromatogram GC dipaparkan pada Gambar 4 menunjukan adanya 7 puncak yang artinya ada 7 senyawa. Senyawa yang paling dominan teridentifikasi adalah senyawa dengan nomor puncak 1, 3, 5, dan 6 . Analisis dengan spektra massa menunjukan bahwa spektra massa puncak 1 dan 5 adalah senyawa eugenol dan spektra massa puncak 3 dan 6 adalah senyawa kariofilen. Senyawasenyawa ini memiliki aktivitas antelmintik, antijamur, antibakteri, dan antioksidan [5-7]. Eugenol juga merupakan bahan dasar sintesis 2hidroksi-3-metoksi-5-propil asetofenon [8].

\section{Kesimpulan}

Komponen-komponen utama minyak daun cengkeh segar dan kering yaitu eugenol dan kariofilen. 


\section{Daftar Pustaka}

1. Nurdjannah, N., Diversifikasi penggunaan cengkeh. Perspektif 2016, 3, (2), 61-70.

2. Listyoarti, F. A.; Nilatari, L. L.; Prihatini, P.; Mahfud, M., Perbandingan Antara Metode Hydro-Distillation dan SteamHydro Distillation dengan pemanfaatan Microwave Terhadap Jumlah Rendemenserta Mutu Minyak Daun Cengkeh. Jurnal Teknik ITS 2014, 3, (1), F39-F43.

3. Supriatna, A.; Rambitan, U. N.; Sumangat, D.; Nurdjannah, N., Analisis sitem perencanaan model pengembangan agroindustri minyak daun cengkeh: studi kasus di Sulawesi Utara. Buletin Penelitian Tanaman Rempah dan Obat 2015, 15, (1), 118.

4. Ngadiwiyana, N.; Ismiyarto, I.; Jumina, J.; Anwar, C., Sintesis 3-(3, 4Dimetoksifenil)-Propanal sebagai Senyawa Antara dalam Pembuatan Turunan Antiboitik C-9154 dari Minyak Daun Cengkeh. Jurnal Kimia Sains dan Aplikasi 2008, 11, (2), 38-42.

5. Pessoa, L.; Morais, S.; Bevilaqua, C.; Luciano, J., Anthelmintic activity of essential oil of Ocimum gratissimum Linn. and eugenol against Haemonchus contortus. Veterinary parasitology 2002, 109, (1-2), 59-63.

6. Deans, S.; Noble, R.; Hiltunen, R.; Wuryani, W.; Penzes, L., Antimicrobial and antioxidant properties of Syzygium aromaticum (L.) Merr. \& Perry: impact upon bacteria, fungi and fatty acid levels in ageing mice. Flavour and Fragrance Journal 1995, 10, (5), 323-328.

7. Pinto, E.; Vale-Silva, L.; Cavaleiro, C.; Salgueiro, L., Antifungal activity of the clove essential oil from Syzygium aromaticum on Candida, Aspergillus and dermatophyte species. Journal of medical microbiology 2009, 58, (11), 1454-1462.

8. Wulansari, F. D.; Matsjeh, S., Sintesis 2hidroksi-3-metoksi-5-propil asetofenon dari Eugenol. 2010. 